\title{
Culture in the European East-Baltic Periphery: Embarrassed Coexistence of Fashion, Officialism and Resistance. The Estonian Case of K. J. Peterson
}

\author{
JÜRI TALVET
}

\begin{abstract}
Despite some historically conditioned differences between three Eastern-Baltic cultures, none of them seems to have had sufficient defence mechanisms to develop any substantial resistance to powerful cultural fashions and officialism in culture imposed by major centres of economical-political power of Europe and the West in the different stages of their cultural history. A more detailed and concrete analysis of these processes has hardly been possible, as the mutual access to the "other" in its respective permutations has been deficient and highly fragmented. Genuinely comparative cultural studies have been quite weak so far even in such fields of creativity as music and visual arts, not to speak of literature, the most complicated and multi-layered creativecultural area, in which the dependence on the vernacular linguistic factor is exclusive and unavoidable.

For the time being - without any guarantee that future could bring some improvement - we can only intuitively grasp some parallel developments. What we can do in the field of comparative literature is to describe and establish the contours of a model of the interaction between fashion, officialism and resistance in one particular ethnic culture. After that first step we can follow to the comparison of all three models, as well as to introduce their correction and modification, describing concrete cases of coincidence, overlapping and also difference.
\end{abstract}

Keywords: culture within culture, fashion, officialism, alienation, resistance

\section{Introduction}

At the start of this new millennium, there have been attempts by some Estonian literary scholars (Jaan Undusk, Liina Lukas, among others) to extend the identifying label "Estonian literature", traditionally adapted to the literature created by the autochthonous Estonians in their native Estonian, to the writing of the Baltic Germans who since the late Middle Ages till the $19^{\text {th }}$ century were the dominant ruling class in Estonia, at the time when the ethnic Estonians themselves were forced to the humiliating status of serfs, thus being deprived 
of their most elementary rights, including literacy and education. The wedding song "Carmen Alexandrinum Esthonicum ad leges Opitij poeticas compositum" (1637) by Reiner Brockmann (1609-1647) has been generally acknowledged as the first poem ever written in the vernacular Estonian language (or the "country language", maakeel, as the autochthonous peasant folk themselves called their language). Brockmann was a Baltic-German professor of Greek and a clergyman who had friendly personal relations with the first significant lyrical German poet of the new era, Paul Fleming, during the latter's short stay in Estonia in the 1630s. Both young men followed the fresh new turn in German poetry set by Martin Opitz. Especially our younger generation of classical philologists have researched in great detail Brockmann's work (thus, Marju Lepajõe's thorough study of Brockmann's work in Latin, German and Estonian; Lepajõe 2000).

However, it also remains an undisputed fact that the alexandrine, though employed by Brockmann's in the historically inaugural Estonian poem, as a poetic form has never enjoyed any significant success in the subsequent tradition of Estonian poetry, though it naturally has been practiced in the Estonian translations of French, German, Spanish and maybe other alexandrines.

On the other hand, the poetic work of Kristian Jaak Peterson (1801-1822), unanimously considered to be the first significant Estonian autochthonous poet, has also remained somewhat alien to the subsequent mainstream of Estonian poetry taking shape since the time of the "national awakening" in the second half of the $19^{\text {th }}$ century. Despite his unjustly short lifespan, Peterson not only excelled as a poet, but revealed his great talents and awakened spirit in researching the Estonian language as well as meditating about human existence in its broadest sense. After the abolishment of serfdom, he was one of the early autochthonous Estonians who matriculated at the University of Tartu.

Peterson's father was a serf from the region of Viljandi, but thanks to lucky circumstances not known to us he could move in the 1790s to Riga, where he was a workman at the shop of a German and a church servant. Peterson's mother was of Russian origin. In the biggest city of the East-Baltic region, Riga - where J. G. Herder, the great ideologist of the early European Romanticism, stayed in the 1760s and wrote his first influential essays - Peterson went to a district school and a high school where he learned Latin, Greek, Russian and French, besides knowing his father's language, Estonian, and, naturally, German. Later he learned independently Swedish and translated from that language into German Christfrid Ganander's book Mythologia Fennica (1789), published at the end of his life in 1821/1822.

Peterson's poems in his diary were fated to remain in manuscript which with other manuscripts remained in the hands of Johann Heinrich Rosenplänter, a Baltic-German educator and editor (born in Valmiera (1782-1845), who since 
Culture in the European East-Baltic Periphery

1809 was active as a Lutheran pastor in Pärnu and published a series of research papers Beiträge zur genauern Kenntniss der ehstnischen Sprache 1813-1832, 3500 pp.) where Peterson collaborated.

Peterson's first poems ever published appeared exactly a hundred years after his birth, in 1901, in Eesti Üliõpilaste Seltsi Album, introduced by Villem Reiman (Taev 1976: 20). In the following, the leading Noor-Eesti poet Gustav Suits discovered Peterson the poet for the wider Estonian audience by publishing 13 poems in the almanac of Noor-Eesti (III-IV, 1910-1911). In its entirety, Peterson's Estonian diaries and poems appeared for the first time in 1922. A new book of Peterson's complete work in Estonian was edited by Karl Taev in 1976.

\section{Originality versus fashion}

It is but natural that any poet at least in the initial stage of his/ her work relies consciously or unconsciously - on a certain established manner, fashion or style. Peterson could not escape this. By that time, some enlightened Baltic-Germans had turned their attention to the Baltic's rich treasury of oral folksongs and had collected these songs. Herder included several Estonian, Latvian and Lithuanian folksongs in his important book Stimmen der Völker in Liedern (composed in 1778/79). Quite a few of Peterson's poems follow the basically trochaic rhythm of Estonian (and Finnish) folksongs.

On the other hand, much stronger aesthetic support to his activity as a poet came from outside Estonia. These influences have been traced a long time ago. As Peterson is especially famous for some of his odes, the most influential immediate forerunners in German literature were naturally Friedrich Gottlieb Klopstock (whom Peterson mentions in his diaries), but he must have known also the work of Goethe and Schiller (though he never mentions them in his writings). Besides, in the diaries also Peterson's contemporary Swedish poet of Karelian-Finnish origin Frans Michael Franzén (1772-1847) has a special mention.

Franzén is generally considered to be the introducer of Swedish romantic poetry. He researched Finnish folklore and mythology, which also attracted Peterson. For that reason the mythological background of the work of both Franzén and Peterson radically differs from the sources of German, English and other European poets of the "centric" Germanic-Romanic area. I would call it one of the first symptoms of a cultural resistance departing from the European "periphery". It was a search for a Nordic identity, originality and independence.

Thus Peterson wrote in his diaries (Peterson 1976: 106, translation is mine - J. T.): 
TALVET

Oh, how good it would be if every country could be satisfied with what it has, because the same god that gave to Italy orange trees gave to the Nordic country proud oaks, and both of them are beautiful by their own origin. Therefore it is very true what the Swedish man [Franzén] sings. (Peterson 1976: 106)

In the following Peterson quotes two fragments from a poem in the Swedish language by Franzén, with the initial line: "Ingen Erato på Tules fjallar / Gratierna böd till dans." The main idea of Franzén in the poem is that classical Mediterranean poetics cannot produce great fruit in the North. In the second fragment, Franzén is sceptical about Georg Stiernhielm's introduction in the $17^{\text {th }}$ century of hexameter, alexandrine, classical Greek and Roman mythology as well as Renaissance poetical forms in the Swedish language poetry. He says they were destined to lack in the north the fire splashed by the sun over the landscapes of Mantua and Lesbos... (Ibid.)

Although God appears in a number of Peterson's odes, the poet never identifies it (him? her?) with Christian God or the classical Greek and Roman deities. Besides, as in Estonian we do not have any grammatical gender distinctions, the supreme spirit or creator simply appears in Peterson's poems as jumal ('god' without the capital initial letter). It is also true that Peterson never includes in his Estonian poems any names from Roman or Greek mythology. It is the more surprising taking into account that Peterson was among the first Estonians ever to have a good knowledge of Latin and Greek to the extent that he himself taught the Greek language.

Instead, Karl Taev is right in observing (Taev 1976: 15) that despite the general similarities of his odes with the imagery and tonality of Klopstock and other Germans poets in their odes - including for instance alternation of long and short phrase cycles, rhetorical questions as well as enjambment - Peterson did not fail to notice in parallel with the cosmic infinity and life's totality the very concrete and local Estonian phenomena. Taev refers above all to Peterson's most famous ode, "Kuu” ('The Moon').

Let me quote here the poem in English translation (by H. L. Hix and myself), published first in Talvet 2010: 471-472:

\section{THE MOON}

Doesn't the wellspring of the song

in the cold Nordic wind

soak the senses

of my people with its mist? 
If here in the snowy North

A pleasant-smelling myrtle

In a windy valley

Can beautifully bloom;

Cannot, then, the native

Tongue of our country

That like a quiet creek,

Without knowing its beauty,

Is running peacefully

Across the meadow,

In the golden fire of the sky,

Or with a sounding voice,

Without knowing its might,

With the heaven's thunder,

When the sea is loudly calling:

Cannot, then, the native tongue

Of this country rise in the wind

Of the song to the heavens

And seek for it eternity?

Then I will sing to you,

The stars of a clear

Blue sky, looking with joy

From the earth

To the high fatherland:

Then I will sing to you,

King of the night, the moon!

You who in the lap of clouds,

Like a flower from its bud

With a merry white face,

Rise under the skies,

Where hot stars

Are falling to the earth

From before you

Into the black and gloomy mist. -

Thus you, human spirit,

You're swimming in the mist,

As your thought is seeking

God from below the stars. 
TALVET

The Estonian scholar and writer Jaan Undusk has recently published a lengthy article in Estonian, with the title "Eesti Pindaros. K. J. Petersoni oodide vaimuloolisest taustast” (Estonian Pindar. About the Intellectual-historical Background of K. J. Peterson's Odes; Undusk 2012). He makes a thorough and appreciative revision of all sources that Peterson could have used for writing his odes, from Pindar (whose work Peterson knew well and who is mentioned, with Horace, in his diaries) to Klopstock, Goethe and other German poets. Undusk considers highly significant the fact that one of Peterson's professors during his very short studies at the university of Tartu was Wilhelm Friedrich Hezel, a specialist in Pindar's odes, who in 1805 published in Riga a book in German for uninitiated readers, explaining Pindar's art of writing odes (Erläuterung auserlesener Oden Pindars).

Undusk's main purpose in his article is to demonstrate that Peterson derived his odes directly from Pindar and not so much from the later German or other European poets. Undusk claims that Peterson, with all his talents, could not invent by himself the type of ode. He defines it as "slender" (in Estonan, sale) ode, in the sense that Peterson applied in his odes very short lines (thus, in "Kuu" the length of verse lines varies mostly from 5 to 7 syllables), abundant enjambments and a phrase-cycle extending through a great number of lines).

However, in the conclusion Undusk has to admit that he could not discover any direct sources for Peterson's "slender odes", though he admits that Goethe above all among the German poets of the era in fact relied on a "slender rhythm" in a number of his poems (Undusk 22). Undusk clearly feels puzzled about how something that in his opinion surely had to have a direct influencing source, could come into being by force of Peterson's own wisdom. Or as he says: "Of one's own wisdom such verses could not be born, such a form has to be learned." (My translation - J. T.; Undusk 2012: 27).

At the same time Undusk confirms that Peterson's poetry, highly original in its form, could be considered as Estonia's first contribution to world literature. (Ibid. 26)

\section{Yuri Lotman's theory of "paradigmatic" "explosions" and "leaps"}

Now I come to my main assertion. It is supported by the theory of Yuri M. Lotman who already at the start of the 1970s established for literary creation two basic types of structural-semantic patterns: "syntagmatic" and "paradigmatic". The former is more characteristic of prose writing, while the latter is revealed above all in poetic expression. (Lotman 1972: 20,39) In Lotman's late works, the metaphoric image of cultural "explosion" and "leap" can be seen as an extension 
of his early observations about the "paradigmatic" nature of poetry (as a micromodel and epitome for all cultural creation). These ideas are most visible in Lotman's last book published in his life, Lotman 1992. There Lotman is above all attracted by the "unpredictability" of cultural-creative "explosions" and "leaps", which basically differ in cultural history from logically or "syntagmatically" expanding processes.

Naturally, all culture is created in a kind of a "syntagmatic" sequence or space, starting from its very vehicle, language or the means of expression in its most general sense. No artist can escape its influence and framework. However, I can only underline the importance of Lotman's theoretical metaphors, as regards the understanding of the deeper essence of poetic creation. If we merely apply the idea of a perpetually direct intertextuality (sources and influences, especially in the merely formal sense) we would definitely fail to grasp the fundamental renovation and permanent modification of the world's poetic canon, which is a historically undeniable fact. "Explosions", "leaps" and "paradigmatic" elements are by the way not at all alien to literary creation in the prose form. On the contrary, I would claim that there is hardly any major masterpiece of prose fiction in the history and canon of world literature that would be alien to poetic-metaphoric imagery.

\section{Aesthetics and philosophy}

Ars poetica should not in my opinion be understood in a narrowly formal sense, concerning exclusively metrical, rhyme and rhythm patterns, sets of motives, rhetorical elements, etc. Nothing of it is alien to poetry, but I do not think separating formal aspects from the philosophic-ethical content could lead research to any significant conclusions or explain why a particular poetic work has transcended in its significance national-linguistic frontiers, to become part of the world poetry canon.

On the contrary, I would claim that in most major masterpieces of world poetic tradition the novelty of aesthetic dimension is essentially supported by a radically original position in the poet's philosophic-ethic understanding of the world and its particular parts. I would even dare to assert that the mightiest "explosions" in the poetic tradition and ars poetica have become reality as a symbiotic coincidence of both aspects. Aesthetics thus penetrates deep into a poet's philosophy and ethicality, and vice versa.

It is time to return to the notions of "fashion", "officialism" and "resistance", introduced at the start of my present essay. The peaks of change and renovation in the world poetic tradition have nearly always meant at the same time 
"resistance" both to (aesthetic) "fashion" and to power-imposed "officialism" in ideology (which is hardly ever alien to ethical-philosophic aspects of our existence).

There is both ideologically and aesthetically an abyss between the humorously explicative short poem in German which Brockmann added to his "Carmen Alexandrinum Esthonicum" and Peterson's "Kuu”.

In his poem written in short line couplets Brockmann wittily evokes an idyll of everybody - both the ethnic Estonian peasant people and the foreign (BalticGerman) ruling class - speaking the vernacular Estonian language in Estonia. Thus, he concludes, he had the idea of writing in the local language, Estonian:

Lectori Carminis Esthonici

Andre mögn ein anders treiben; Ich hab wollen Estnisch schreiben.

Esthnisch redet man in Lande /

Esthnisch redet man am Strande /

Esthnisch redt man in der Mauren /

Esthnisch reden auch die Bauren /

Esthnisch reden Edelleute /

Die Gelährten gleichfals heute.

Esthnisch reden auch die Damen /

Esthnisch / die auß Teutschland kamen.

Esthnisch reden jung und alte.

Sieh / was man von Esthnisch halte?

Esthnisch man in Kirchen höret /

Da Gott selber Esthnisch lehret.

Auch die klugen Piererinnen

Jetz das Esthnisch lieb gewinnen.

Ich hab wollen Estnisch schreiben;

Andre mögn ein anders treiben.

(Brockmann 2000: 94-95)

It is true that Brockmann had great sympathy for the autochthonous people and their language. He was obviously attracted by the local exoticism. Creating some poems in Estonian in his case, however, could hardly amount to anything beyond a mere caprice. His poems in Estonian were written in a primitive language, because the Estonian language - even though at that time it started to be taught to the ethnic peasant people themselves at church schools -was still in its very elementary shape. The bulk of Brockmann's poems were written either in German or Latin. Had Brockmann started consciously to fight for the 
elementary human rights of the ethnic Estonians, to all probability he would have been banished from Estonia to his homeland, to the dukedom of Mecklenburg where he was born...

Aesthetically, Brockmann belonged to those young Germans intellectuals who became fond of Martin Opitz's poetical renovation. He followed the fashion, writing in Alexandrines which not long ago had been "imported" by his compatriots from France. In the histories of German poetry or literature, Brockmann is hardly ever mentioned.

\section{K. J. Peterson's philosophy and poetics}

Differently from the case of Brockmann, the achievement of Peterson at the earliest stage of a conscious Estonian autochthonous poetic could be compared to the "explosion" that took place in European poetry in the work of the great Italian Dante Alighieri. Naturally, there is no denying that our "peripheral" Peterson could not rival the influence Dante has had for all posterity in the Western poetic tradition. However, Dante Alighieri and Peterson coincide in the nature of their poetic deed. Both were philosophically minded poets, with a strong and original ethicality forming the nucleus of their universe of the mind. Just like Dante, who wrote the first fully serious philosophical treatise, Convivio, in the vernacular Italian (Tuscan) language, defying the supremacy of Latin, half a millennium later Peterson did the same, as regards the Estonian language: he not only voiced in the above quoted poem "Kuu" his famous existential question: "cannot, then, the native tongue / of this country rise in the wind / of the song to the heavens / and seek for it eternity?", but he demonstrated in the same poem and several others that indeed that language, the Estonian language, could rise in his creation to the heavens, just like Dante had before him sought eternity in his Divina Commedia.

In Dante, love for a young woman became the incentive for seeking perfection and salvation in divine love. The traditional "other", woman, thus entered the reign of philosophy, being turned by the poet into the principal guide to divine truth for the mortals. Ethics, the field in which philosophy becomes unalienable from the "other", occupied in Dante's philosophy the higher heavenly sphere than metaphysics, being second only to theology.

Peterson in his Diaries evokes a logical conclusion made by his little sister: "If humans have heaven, then animals or beasts must also have heaven, because they too have a soul in them." (Peterson 1976: 101; my translation - J. T.)

It is an allusive criticism of the anthropocentric foundation that had sustained the Christian church for long centuries. Peterson's thoughts in his Diaries 
reveal his intuitive feeling of life's totality as the very basis of existence. The same philosophy of life's wholeness - close to what has been called holism in modern terms -, reappeared afterwards in the world-view of F. R. Kreutzwald in his epic Kalevipoeg (1861), as well as in the lyrical work of Juhan Liiv, at the start of the $20^{\text {th }}$ century. In both, a radical shift away from the hitherto dominating male-centred ethics is obvious, but in all likelihood the deep influence reaching from them to our days can only be explained by the concomitant aesthetic novelty of their work, as was the case with Dante and Peterson.

I will not go into greater detail discussing the generic aspects of the "other" in Peterson's poetry. He wrote a number of pastoral eclogues, mostly relying on the metrics of the traditional Estonian (and Finno-Ugric) folksong. In several poems, but especially in "Alo ning Jaak. Karjaste laul” (Alo and Jaak. Shepherds' Song) the friendship between two young shepherds, Jaak and Alo, is depicted in openly homoerotic and sensual terms. Thus Jaak in his song says: "Honeybee flies / to pussy (willow catkin)./ But I fly / to the face of Alo / to look for his mouth / in the rosy spring. [...] On the top of a pine-tree / a little bird sleeps / in its nest./ But I sleep / in the lap / of my Alo - / Thus, dear Alo, / I am blessed. / Because my Alo / loves me ever." (Peterson 1976: 51-52; my translation - J. T.)

In passing one could mention that in the subsequent Estonian literature homosexuality was almost a taboo topic. In the Soviet period after World War Two it was an officially established taboo. Only after the newly restored independence (1991) homosexuality has appeared in the novels of Tõnu Õnnepalu (alias Emil Tode). In the work of Estonian exile writers, shades of homosexual motifs have been traced in the prose fiction of Karl Ristikivi, who lived and died in Sweden. Thus Peterson can be seen as a "pioneering" Estonian writer in this respect.

However, I would not attribute any greater importance to this detail. Excellence in literature is seldom achieved by the mere novelty of a topic. Besides, as in the case of Walt Whitman, it would be difficult to prove that Peterson was a homosexual. The motive of love between males could well be a part of both poets' general philosophy of openness to life's totality and love that united all the living world. In Peterson, his homoerotic love songs could also have been predicted by a certain manner or fashion, following ancient Greek pastoral love lyrics, of which Peterson was well aware.

Not only young men (Jaak and Alo, Jaak and Jüri, Ott and Peedo) appear singing to each other in Peterson's eclogues. Also the noble feeling of two young Estonian shepherdesses, Elts and Tiio, are reflected, while in one of the eclogues there is a mixed pair of young shepherds in love, Enn and Elo. Ambiguity remains in "Karjaste laul ehk Jaagu leinalaul" ('A Shepherds's Song or Jaak's Dirge'). Jaak grieves there because his love has abandoned him. However, 
throughout the poem Peterson applies to the loved person the pronoun "tema" which in Estonian, a language devoid of the grammatical gender category, is common to both genders.

As for women, Peterson exalts their beauty in a short poem of six-syllable trochaic lines:

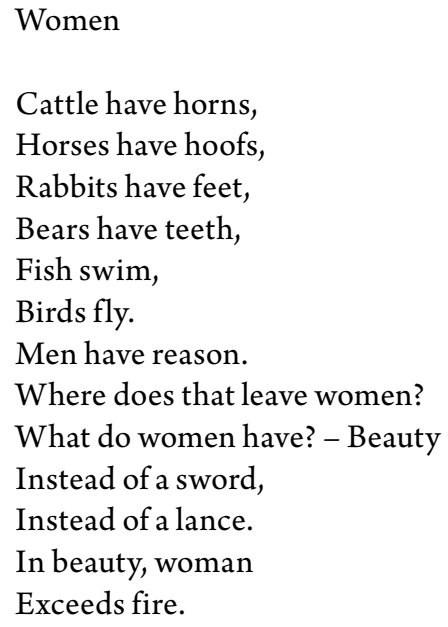

(Peterson 1976: 49; trans. J. Talvet and H. L. Hix)

By far more important are other aspects framing Peterson's general philosophic stand in favour of Nordic and Estonian identity, as opposed to the imitation of poetic patterns / fashions derived directly either from the ancients or from Romanic and Germanic poetic manners and language.

The solid stem of the greatness Dante's Divine Comedy both in the philosophical as well as the aesthetic sense is its intrinsic relatedness to the localhistorical-coeval reality, the concretely sensual - the Italian ambience, language, culture, poetics. A similar strive can easily be observed in our Peterson. He naturally followed in his eclogues and pastoral poems a fashion coming from the ancient Greeks, but the novelty is that the shepherds appearing there are all Estonians and they sing in the Estonian language. There are lots of local details identifying the ambience as Estonian. The birds, the animals, the trees and plants in his poems are mostly typically Estonian or at least Nordic. In "Jaak ja Jüri - karjapoisid" ('Jaak and Jüri - Shepherd Boys') the moon rises from the river Emajõgi (Mother River, which crosses the town of Tartu and has a special significance for the Estonians as the mother river feeding Estonian culture). They are probably brothers mourning their old father who has passed away. 
The poem follows exactly the trochaic tetrameter typical of the Finno-Ugric folksong. Also, its images are close to those that can be found in the Estonian folksongs: "Like the moon in autumn / shines on a withered flower, / the moon through the window / shines on his grey head. / As blowing through the blades of grass, / the wind blows quietly / through his white hair." (Peterson 1976: 33; my translation $-\mathrm{J}$. T.)

However, it is also highly significant that while employing in several of his poems the traditional folksong meter, Peterson varied it in other poems with a trimetric trochee, thus making the verse line even more "slender" than they look in the folksong. Thus in "Karjaste laul. Ott ning Peedo" ('A Shepherds' Song. Ott and Peedo') Peterson employs in the initial two stanzas and also in the last stanza trochaic tetrameter, while the main part of the poem (six short stanzas) develops in trochaic trimeter. There is irregularity also in the number of the lines in some stanzas. (Peterson 1976: 43)

Like the $12^{\text {th }}$-century Provencal troubadours and the German love poets long before him, Peterson reveals a conscious search for new poetic rhythms, feeling at the same time the natural possibilities of the Estonian language. Formal renovation has been a concomitant feature of the work of many poets of the past, starting with most ancient poetry. However, I would once again stress the parallel between Dante and Peterson in the sense of a coincidence in both of a strong philosophic-ethical individuality and formal-poetical renovation against the background of a search for a genuinely original turn, providing identity for their respective native-ethnical poetic creation and culture. It means at the same time a search for cultural identification of their respective nations in the wider map of world poetry and culture. The noble universal mission of a poet is outstandingly resumed in Peterson's poem "Laulja” ('The Singer', Peterson 1976: 60):

Like roaring rapids

Of whitewater

Tumbling from peak

Down to valley;

Like lightning

From storm clouds

Striking awfully,

Thus surges the brilliant

Burning current of a song.

Like a stream of light, The venerable singer stands

Amid his brothers.

A thunderclap 
Silences the forest:

The singer is lifting

His voice, from his mouth

Falls a dew of song,

And around him

Silent as rocks in the sea,

Nations listen.

(Trans. J. Talvet and H. L. Hix)

\section{Poetic renovation under the sign of resistance}

To sum up the above said. In the work of some of the greatest writers and poets, creative "explosions" can never be explained by mere sequences of intertextualities. There are poets whose originality and novelty cannot be explained exhaustively by influences coming from preceding or their contemporary literature. They have been the core of poetic renovation of all times. To express fully his ethics and philosophy, Dante let it merge with the totally novel verse form of his Divina Commedia, the terza rima invented by nobody else but himself. Likewise, there is little reason not to consider our Peterson among the introducers of free unrhymed verse in the Western poetic tradition, especially in its "slender" variety.

Short verse lines were widely employed both in traditional and cultured poetry since the late Middle Ages. However, it is true that in most cases in such poems of short lines sporadic if not regular end-rhymes were used. The same was echoed by a number of romantic poets (thus Schiller and Goethe, Shelley, Byron, among others). Let alone regular blank verse (widely employed in the English poetic tradition since the epoch of Shakespeare), free verse devoid of end-rhymes started to take shape gradually on the basis of the adaptation of ancient meters to poetry in modern languages. William Blake in his extensive prophetic-allegoric and symbolist poems (e.g. "Vala", "Jerusalem") written at the start of the $19^{\text {th }}$ century - thus coinciding in time with Peterson - employed a very long line (from 13 to 16 syllables) without end-rhymes. However, a genuine breakthrough occurred after the death of Blake and Peterson in the work of the great American Walt Whitman in the middle of the $19^{\text {th }}$ century. To all probability it was because Whitman turned to a completely novel matter - his contemporary everyday reality in its very concrete historical and sensually perceived form -, detaching himself boldly from the vast burden of allegorical-symbolist imagery that Blake, for instance, borrowed from the legacy of the $17^{\text {th }}$ - and $18^{\text {th }}$. century if not earlier poetic tradition. 
TALVET

The short or "slender" verse line used by Peterson in his odes could have been predicted on the one hand by the traditional Finno-Ugric folk-poetry rhythm, which is also short (but as was mentioned, Peterson cut it even shorter). However, as a genuinely creative poet, Peterson apparently was not satisfied with thus restricting his poetic expression to the rather monotonous folksong pattern, but sought to introduce something different and at the same time not "imported" from the poetic tradition of Romanic and Germanic people.

Yet there is one more important aspect that might have encouraged Peterson to try his own novel way of introducing unrhymed free verse without endrhymes. Despite his unjustly short lifespan he consciously researched Estonian language. It is utterly unlikely that he was unable to write poems relying on endrhymes. Peterson must have grasped from the very beginning the predominant nature of the Estonian language contradicting end-rhyme as a phenomenon. Our folk-poetry did not use end-rhymes because there are incomparably less possibilities for achieving them in our language than, for instance, in Romanic, Germanic and Slavic languages. End-rhymes have been an exclusively imported poetic phenomenon since Martin Opitz established his influential poetics for the Germans and the German Brockmann wrote his poems in the elementary Estonian language.

Unfortunately, the mainstream of Estonian poetry ever since adapted endrhyme patterns and their metrics as something that "should grant" Estonian poetry a worthy place in the world's "cultured" poetry, derived above all from the poetic traditions of the major Western nations. As far as I see it, adapting the traditional folksong verse rhythm was the main premise of the success of F. R. Kreutzwald's epic Kalevipoeg (1861), the work which despite some criticism on the part of the younger symbolist poets and literary men has been unanimously celebrated as the cornerstone of Estonian literature. Kreutzwald's own poetic talent is fully revealed in this pattern. The epic means the consummation of the Estonian rich folksong tradition, the great heritage of the oral creation of Estonian peasant-women. Notwithstanding the obvious translation difficulties, the epic has been translated by today in its full form into thirteen languages of the world. It is also symptomatic that when Kreutzwald in his old age tried to create another national-philosophic epic, Lembitu (published posthumously in 1885), in octaves - in a major "cultured" poetic pattern for epic poetry, widely used since the Italian renaissance - he inevitably failed, not because of his philosophic aspirations, but just stumbling over the poetic form. It would indeed be impossible to achieve in an extensive epic work in Estonian full end-rhymes that would match the exigent rhyme requirements of ottava rima.

Also symptomatically, Juhan Liiv - for many, the greatest lyrical poet Estonian has had - consciously rebelled against strict end-rhymes, trying to avoid 
them by relying on inexact and loosely arranged assonant rhymes. Like Peterson, he was well aware of the extremely limited range of strict rhyming words in the Estonian language. As Liiv suffered from mental illness, his observations about rhyme were not taken seriously by the younger writers of "Young Estonia" (Noor-Eesti) group at the start of the $20^{\text {th }}$ century. However, the same group established by its cultured authority the mainstream of Estonian poetry that endured at least till the start of the 1960s, when free verse without end-rhyme finally started to gain ground.

\title{
Conclusion
}

I would thus qualify Peterson, our first great Estonian poet, under the sign of resistance. He sought original Estonian expression in poetry, in harmony with the nature of the Estonian language. He rejected fashion - hitherto dominating Western mainstream formal poetic patterns -, as well as the ideological officialism which in those times crudely neglected the cultural needs of minor ethnical communities. Peterson can be seen as a great forerunner of freer poetic forms as well as of a new ethical philosophy.

There is a serious doubt if we, the Baltic literary scholars, ever manage to write a comprehensive history of East-Baltic literatures. At its best it could be a mechanical outline compilation of the literary phenomena and tradition in our countries. There are very few hopes that our critics and the reading public would ever get access in equal parts to all three literary traditions.

However, to end on a more optimistic note, I am sure that if ever we manage to purposefully extend our comparative literary-cultural studies - that means first and foremost the research of our East-Baltic literatures in the wider context of Western and world literature -, we would be able to enlighten in a novel way at least some most important phenomena and segments of our literatures. Instead of self-myths conceived exclusively from the inside of our linguistic-cultural communities, comparative research would provide us with a much firmer ground for presenting in the (ever expanding and never closed) map of world literature the spiritual achievements of our writers, Latvians, Lithuanians, Estonians.

\author{
Jüri Talvet \\ talvet@ut.ee \\ Tartu Ülikool \\ Maailmakirjanduse õppetool \\ Ülikooli 17-403 \\ 51014 Tartu \\ EESTI
}


TALVET

\section{References}

Lepajõe, M. 2000. Reiner Brockmanni ladina-, kreeka- ja saksakeelsest luulest. R. Brockmann, Teosed. (Ed. Endel Priidel). Tartu: Ilmamaa, 41-51.

Lotman, Y. M. 1972. Analiz poètičeskogo teksta. Leningrad: Prosveŝenie. = Һотман Ю. М. 1972. Анализ поэтического текста. АенинграА: Просвещение.

Lotman, Y. M. 1992. Kul'tura i vzryv. Moskva: Progress. = Һотман Ю. М. 1992. Культура и взрыв. Москва: Прогресс. (In English: Lotman, Y. M. 2009. Culture and Explosion. Trans. Wilma Clark. Berlin, New York: Mouton de Gruyter.)

Peterson, K. J. 1976. Laulud. Päevaraamat. (Ed. Karl Taev). Tallinn: Eesti Raamat.

Taev, K. 1976. Eessõna. - Kristian Jaak Peterson. Laulud. Päevaraamat. Ed. Karl Taev. Tallinn: Eesti Raamat, 5-29.

Talvet, J. 2010. Estonian Poetry: The Seduction and the Toil of Thinking in Rhymes. Forum for World Literature Studies, Vol.2, No. 3, Dec. 2010, 468-486.

Undusk, J. 2012. Eesti Pindaros. K. J. Petersoni oodide vaimuloolisest taustast. - Keel ja Kirjandus, 1, 11-29; 2, 103-122). 